Volume 8

Issue 3 Humanitarian Technologies and

Genocide Prevention

Article 10

October 2014

\title{
Humanitarian Technologies and Genocide Prevention: A Critical Inquiry
}

Colette Mazzucelli

New York University

Follow this and additional works at: https://digitalcommons.usf.edu/gsp

\section{Recommended Citation}

Mazzucelli, Colette (2014) "Humanitarian Technologies and Genocide Prevention: A Critical Inquiry," Genocide Studies and Prevention: An International Journal: Vol. 8: Iss. 3: 87-99.

DOI:

http://dx.doi.org/10.5038/1911-9933.8.3.8

Available at: https://digitalcommons.usf.edu/gsp/vol8/iss3/10

This is brought to you for free and open access by the Open Access Journals at Digital Commons @ University of South Florida. It has been accepted for inclusion in Genocide Studies and Prevention: An International Journal by an authorized editor of Digital Commons @ University of South Florida. For more information, please contact digitalcommons@usf.edu. 


\section{Humanitarian Technologies and Genocide Prevention: A Critical Inquiry}

Colette Mazzucelli*

New York University

New York, NY, USA

Keywords: genocide prevention, humanitarian technologies, human rights

\section{Introduction}

The prevalence of conflict within states, specifically after the end of the Cold War, continues to influence teaching and research in genocide studies ${ }^{1}$ as scholars reflect on the emergence and evolution of the field since the late 1970s. ${ }^{2}$ State fragmentation and the collapse of empire notably in the former Soviet Union led to a shift in focus away from primarily structural or systemic-based explanations to identity or local-oriented inquiries. Fundamental transformations influenced by the information and communications technology (ICT) revolution and "a novel redistribution of power among states, markets and civil society"3 mark our experience of globalization at the start of the $21^{\text {st }}$ century. States, particularly the most powerful, must confront the "marketplace of ideas" and the "movement of public opinion"4 as the proliferation of non-governmental organizations (NGOs) and the strength of "networked actors"s lead to "new approaches to activism".6 "Networked politics" is emerging with a particular relevance to genocide studies as an approach that "focuses on networks as actors where networks are particular forms of coordinated collective action aimed at influencing international outcomes". The ability of what Owen defines as "networked actors" to influence outcomes, using their power in both positive and negative ways, matters decisively in our world today. More specifically, "new forms of action that are enabled by networked technology" must prompt reflective, critical inquiry and analysis; how do humanitarian technologies and their impact over time matter to the study and, more fundamentally, the prevention of genocide as well as individual human experiences of transitional justice? ${ }^{10}$

\section{Anchoring the "Local-Level" in Genocide Matters}

A recent initiative, Build Peace, is creating a unique community of practitioners, activists, technologists, and scholars to chart the future of technology and its impact on the ground in conflict transformation. Led by Helena Puig Larrauri, Michaela Ledesma, Rodrigo Davies, and Jennifer Welch, Build Peace convened an initial conference held at the MIT Media Lab on 5-6 April 2014. ${ }^{11}$ The various panels and working sessions organized that weekend continue to initiate conversations pertinent to an evaluation of humanitarian technologies. How do these on-going discussions inspire our critical analysis as a scholarly community of the relevance of humanitarian technologies in the context of "preventing genocide?"12

The Build Peace conference underlines the necessity to study local contexts before even thinking about the ways humanitarian technologies may support conflict transformation. This point is most relevant in cases of genocide prevention, particularly given the need for a thorough understanding of the culture, history, languages, politics, and religions in a society as well as its legal system, which often influences access to elementary, secondary, and university education, public sector employment, and the allocation by state leaders of resources among different groups.

As the study of comparative genocide theory expands, scholars undertake research that integrates a variety of disciplines, including critical theory and post-colonial approaches. This evolution since the 1980s raises questions about the "definitional boundaries" of genocide studies as a distinct academic field. ${ }^{13}$ Is Darfur a "civil war" or should we use "genocide" to explain mass violence in Sudan? The emergence of humanitarian technologies induces us to question the specific role of civil society, in its local and transnational dimensions, ${ }^{14}$ to sustain a debate in the "global public sphere"15 that is less about the character of the conflict and more focused on the information necessary to help citizens "recognize emerging intergroup tensions that are likely to lead to violent abuses.".16

Contemporary analyses delve more deeply "to acknowledge the diversity of civil society actors, discourses, and agendas....alongside states and international organizations in the politics of genocide" emphasizing "the

*The author expresses her appreciation to Kyle Matthews, Cristian M. Silva Zuniga, Stefan Schmitt, Tristan Brand, and Jen Ziemke. 
dynamics of contestation and struggle" as well as "the role of civil society actors in shaping the evolving global humanitarian regime to guide the international response to any particular crisis". ${ }^{17}$ These analyses miss the mark in the ways societal actors must engage with humanitarian technologies to prevent genocide. The adaptation of remote sensing and satellite imagery must strengthen the proactive capability of humanitarian technologies to provide accurate, consistent, and early detection.

Of critical importance is the ways in which early detection is combined with the strategic use of social media to convey, as broadly as possible, verifiable information. Reports of propaganda campaigns or largescale displacement or hate $\operatorname{speech}^{18}$ for example, must be confirmed through a reliable source triangulation process of various inputs, as appropriate to the particular case. Data made available by local village monitors on the ground, via text message, over community radio, broadcast on television, via satellite images, aerial photographs or geospatial content, and/or mapping in cyberspace provides the context in which early detection for genocide prevention may thrive as a result of civil society engagement.

Humanitarian technologies have the potential to sharpen the focus of a prevention lens if their use may support action taken to avert "a lesser atrocity than genocide". ${ }^{19}$ In this context, we must ask if humanitarian technologies have the impact necessary to interrupt oppression ${ }^{20}$ in cases when, for example "...Those who are deemed to no longer belong to the community are stripped of any protection, formal and informal, that membership in the community provides against a predatory state". ${ }^{21}$ To interrupt oppression is defined as the ethical responsibility to engage, which is essential in that "...unresolved hatred and emerging violence in a society can grow into recurrent massacres, even war or genocide, destruction on a vast and hideous scale".22

The difference humanitarian technologies can make depends largely on whether 'civil society', driven primarily by 'accountability', grasps the ethical responsibility to communicate information necessary to counter the 'predatory society, driven often by "violent norms.". The absolute power of an alliance between the 'predatory society' and its counterpart in the state often silences local 'civil society'. For humanitarian technologies to have any chance to be effective as instruments of prevention, the "conspiracy of silence", ${ }^{24}$ which purposefully denies the genocidal intent to perpetrate deliberate and systematic extermination, must be broken. The break must occur from the inside, at the "local-level," on the ground in the specific context where the "emerging intergroup tensions," analyzed by Hamburg, occur.

The decisive importance of the "local-level" is underlined in the analysis of transnational advocacy networks, otherwise known as TANs, in the literature. ${ }^{25}$ The silence of local actors hinders the potential impact of the "boomerang pattern," which aims to address the blockages civil society actors encounter in a repressive state. Outreach by local actors, who seek leverage through pressure on their state by transnational advocacy networks, is critical. In those instances when "emerging intergroup tensions" are a reality, the anchor of the local to the transnational in civil society advocacy provides openings for the use of documented evidence from satellite imagery and remote sensing analyses. The impact of transnational advocacy in tandem with evidence documented through the applications of humanitarian technologies is a subject ripe for prevention research in cases where mass atrocities are likely. Inquiry is needed to shed light on the ways in which transnational advocacy, supported by evidence documented from the ground and sky, may raise the stakes for genocidal leaders who expect to act with impunity.

In this context, Hamburg makes the case for the need "to have information ready at hand about practical measures for prevention that follows the public health model-an approach that uses empirical research to identify high-risk factors and apply a wide array of strategies, tools, and practices for preventing violent outbreaks of all kinds"26 (Figure 1).

For instance, our early reflections and experiences as a genocide studies community regarding the relevance of humanitarian technologies to identify, measure, monitor, document, and research large-scale displacement ${ }^{27}$ as a "precipitating factor" ${ }^{28}$ in the prevention of mass atrocities tend to re-enforce a holistic, interdisciplinary focus in our pedagogy.

The "questioning of geographical boundaries as well as case selection" is salient ${ }^{29}$ in terms of pedagogy, as we integrate applications of humanitarian technologies in the study of genocide and its prevention. As the literature scholars may access grows, anchoring the "local-level" means reflecting on "individual empowerment" ${ }^{30}$ and its significance for prevention efforts. Moreover, research to ascertain the impact of humanitarian technologies on prevention has the potential to open the genocide studies field even further to scholarship from around the world. ${ }^{31}$ Specifically, two developments in recent years, increased affordability of humanitarian technologies and broader social media access to data, allow more recent applications to focus attention worldwide on genocides perpetrated in the Global South. ${ }^{32}$ 


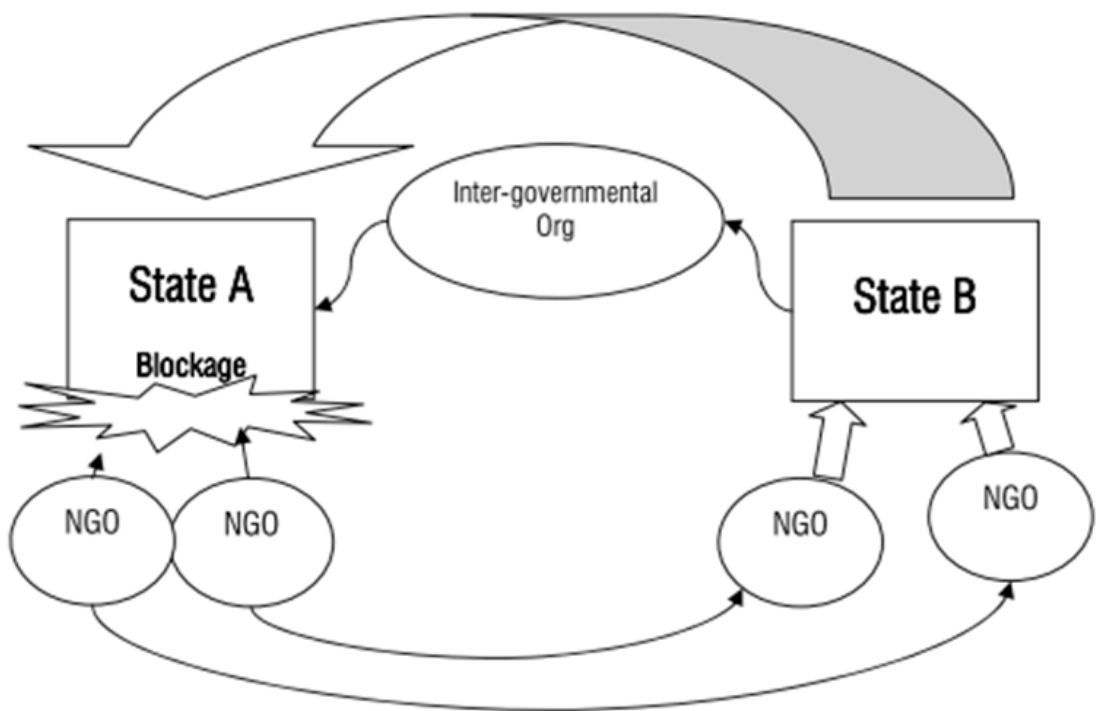

Figure 1. The "boomerang pattern," developed by Keck and Sikkink, to activate TANs. Interrupting Oppression in Repressive States Prone to Mass Violence: Are humanitarian technologies effective in local contexts where civil society encounters its predatory state-society counterparts?

\section{Innovations in Case Selection and Pedagogical Methods} Inquiries in the "Classroom without Borders:" Linking Transitional Justice and Genocide Prevention using Documented Evidence Captured by Humanitarian Technologies

In one noted case study, starting in 2006, Amnesty International USA (AIUSA) in cooperation with the American Association for the Advancement of Science (AAAS), and with a grant from the Save Darfur Coalition, recorded irrefutable evidence of systemic destruction in Darfur. ${ }^{33}$

The most vulnerable populations want "all eyes" to focus continuously on their plight in the hope that genocide may be averted. The "Eyes on Darfur" project did provide ample information of events on the ground. The site is a repository of in-depth analysis as well as individual testimony from the conflict area highlighting displacement of persons as well as destruction of villages (Figure 2). ${ }^{34}$

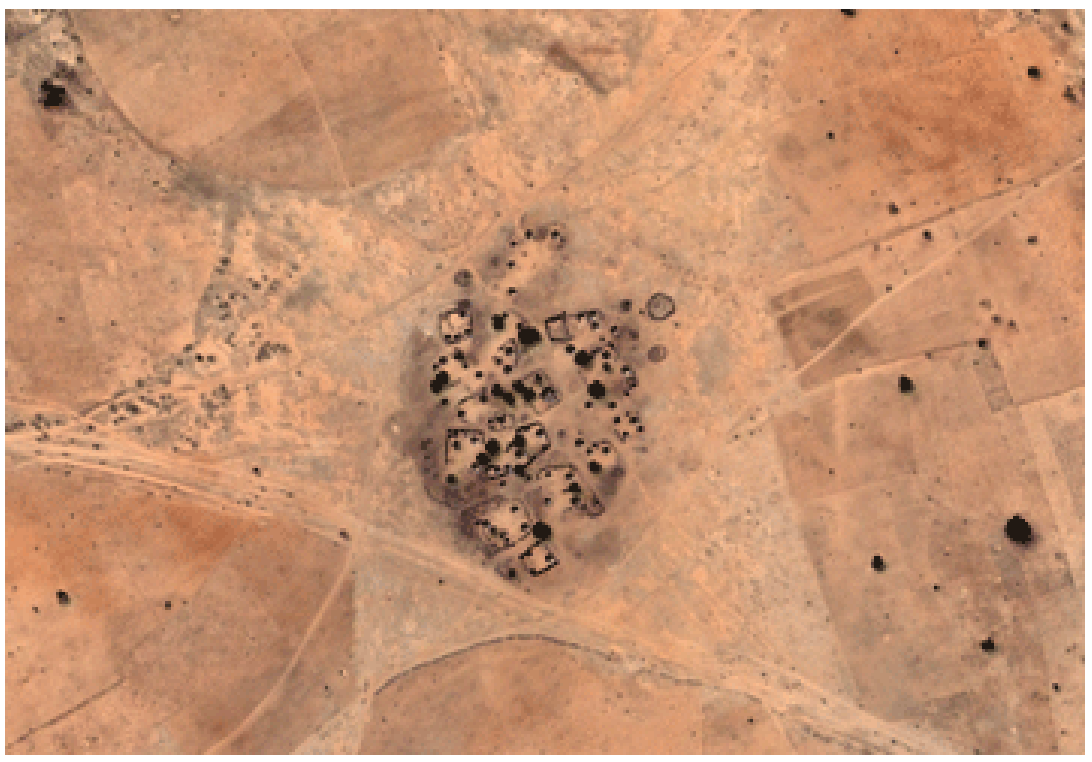

Figure 2. Imagery to Retain a Watchful Eye for Devastation in Ishma, Darfur, 2009, Digital Globe. ${ }^{35}$ 
Yet, we must question the extent to which the use of technology in this project served a deterrent effect. Scott Edwards, in a response to our colleague Patrick Meier, notes that "the mere act of observation...changes nothing about the reality of our world" ${ }^{36}$ To leverage the deterrent power of satellites and other remote sensing tools requires that perpetrators of atrocities fear naming and shaming as well as the documentation of their crimes. The expansion of monitoring capacity however innovative or humanitarian, technologically speaking, is likely to remain limited if at least three other challenges are not addressed simultaneously.

First, local actors encounter critical difficulties to connect with transnational advocacy networks. We must be cognizant of the significant challenges to empower individuals in local settings via their connection with TANs as part of the engagement that defines communication in the global public sphere. Educational inquiries in the "classroom without borders" must assess the possible influence of the "boomerang pattern" comparatively, developing case studies in different geographical locations, and, increasingly, diachronically across diverse time periods. ${ }^{37}$

The concept of the "global network university" implemented at New York University introduces a twentyfirst century idea of learning, research, and service to expand the classroom experience in ways that may animate teaching and facilitate these inquiries.

It is insufficient to question if satellite imagery analysis can also sustain justice by raising the stakes to deter genocidal leaders as long as a second challenge is not met: namely, the need to strengthen the international justice system in ways that give leaders intent on murder cause to fear documented evidence provided by remote sensing, as we expand "the monitoring capacity of watchdogs" ${ }^{38}$

Third, we must reflect on the groundbreaking analysis presented by members of the Satellite Sentinel Project (SSP). This Project, which uses the public deployment of remote sensing and data collection technologies, faced the early challenge of "leveraging SSP's unique information to motivate international response to the alleged abuses in Sudan". ${ }^{39}$ Once again, this observation speaks to the limits of humanitarian technologies in the face of weaknesses inherent in civil society, the international justice system, and political will. Most states do not act to prevent genocide in the national interest. ${ }^{40}$

There is no denial possible in the face of evidence documented to date: remote sensing technologies have broad applicability. Images from the sky capture "widespread destruction of buildings and communities... detect mass graves, document forced displacement, observe troop buildup, document effects of extractive industries, find secret detention facilities" as "the ability of watchdogs to task satellites to capture new images dramatically expands the reach of human rights NGOs". ${ }^{41}$ Of particular importance to a focus on genocide prevention and its relevance to considerations of transitional justice is that satellite images cannot document victims, only crimes. This fact has profound implications in thinking about "restorative justice" with its focus on "the needs of victims and broader society rather than the more narrow demand of punishing violators" ${ }^{42}$

Moreover, if the crime does not leave "a clear and obvious physical effect in space," the "scope and severity of the violations" cannot be assessed without direct access to the area in conflict. ${ }^{43}$ Satellite images cannot demonstrate genocidal intent or conspiracy. Therefore, we must assess their deterrent potential in indirect ways. Can expanding the monitoring capacity of watchdogs offer grassroots actors increased leverage in conflict areas? By forging linkages to NGOs that make transnational advocacy possible, can much-needed efforts to mobilize the will to intervene be sustained by those local actors whose voices most need to be heard? Research inquiries that investigate systematically the expanded uses of humanitarian technologies in areas impacted by mass violence may provide some preliminary answers. Such findings may be of particular relevance as "genocide studies scholars further investigate the challenges of post-conflict settings and engage in advocacy for the prevention and punishment of genocide". ${ }^{44}$ The cross-fertilization between transitional justice and genocide studies will mark the development of each field with connections further established as international courts gather more evidence captured by humanitarian technologies to prosecute violations of international humanitarian law. ${ }^{45}$

The detection and documentation of mass atrocities through the development of standard remote sensing also requires accepted forensic standards. In questioning the relevance of humanitarian technologies to genocide prevention, we must be aware of the gap that is the "absence of a standard approach for the classification of phenomena involving observable objects into categories of observable patterns relevant to certain mass atrocity events". ${ }^{46}$

Before educators analyze the uses of remote sensing platforms and data sensing technologies to explore with students the latest innovations in genocide prevention, it is helpful to introduce knowledge acquired from different field experiences in the "classroom without borders". 47 These initiatives provide first-hand 
encounters with local contexts in which transitional justice concerns intersect with the priorities of genocide prevention. One such encounter occurs regularly during the academic year in Guatemala at the International Field Initiatives and Forensic Training (IFIFI) Multidisciplinary Field School, ${ }^{48}$ in collaboration with the Fundación de Antropología Forense de Guatemala (FAFG), ${ }^{49}$ and especially with the leadership of Fredy Peccerelli, Executive Director, Guatemalan Forensic Anthropology Foundation.

Our colleague Kyle Matthews, Montreal Institute for Genocide and Human Rights Studies (MIGS), Concordia University, travelled to Guatemala with photographer Tristan Brand to observe the work of a group of forensic anthropologists "digging for truth" ${ }^{50}$ as part of a memorialization initiative that "incorporates youth and the new generations in learning about history in order to help prevent the atrocities of the past from being repeated". ${ }^{51}$

The struggle against impunity in post-conflict Guatemala is a restorative project with the objective to "report and publicize past crimes" ${ }^{52}$ Researchers question the role of memory initiatives in dealing with "the culture of silence that perpetuates impunity" by integrating a mapping process, which allows for the recovery of memory of "different violations suffered during the armed conflict" (Figure 3). ${ }^{53}$

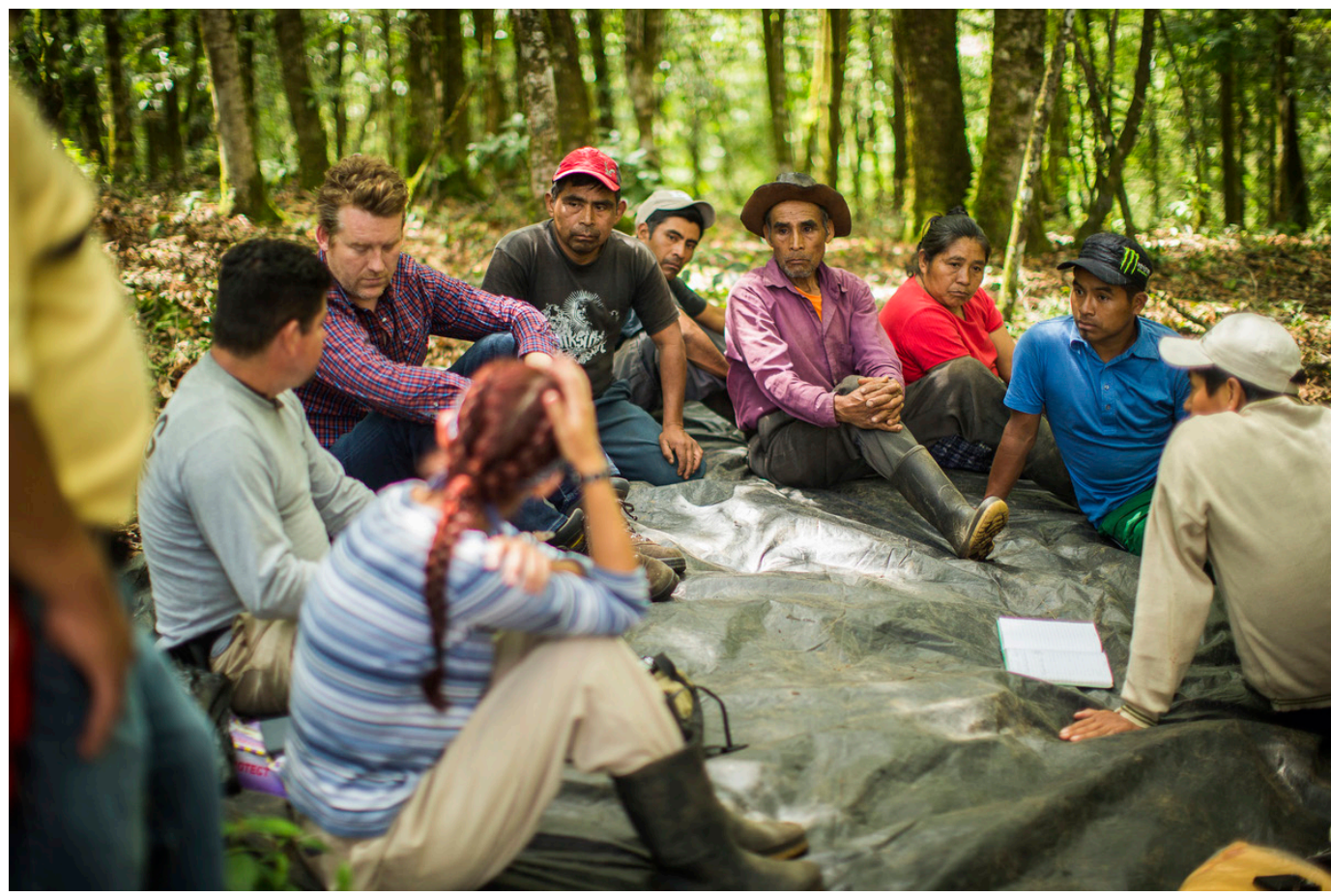

Figure 3. In the highlands of Quiché province, Kyle Matthews, along with other forensic workers, students and local residents, listens to the testimony of a man who recalls the murder of his wife and infant daughter. (Photograph: Tristan Brand). ${ }^{54}$

Unlike official truth commissions, which may not adequately capture local realities ${ }^{55}$ the mapping process is a grassroots effort that aids Guatemalans in the outreach to different social sectors, notably indigenous survivors as well as displaced peoples, in an effort to resist forgetting. ${ }^{56}$ Although humanitarian technologies are increasingly available, their uses remain limited without the necessary forensic evidence gathered on the ground by native populations with the assistance, increasingly, of international students conducting field research (Figure 4).

Humanitarian technologies must continue to adapt in ways that allow for the integration of increasingly large volumes of data gathered in local mapping processes, which utilize forensic anthropology as well as other scientific disciplines, including forensic archaeology, ${ }^{58}$ to gather the necessary evidence as "a first step along the road to societal reconciliation.".59 The groundbreaking work of non-governmental organizations (NGOs) such as Physicians for Human Rights (PHR) is particularly relevant to assess the impact of humanitarian technologies in genocide prevention given the need to map the transitional justice literature to "contribute to furthering useful links and cross-fertilization" ${ }^{\prime 60}$ between transitional justice and genocide 
studies. Innovative pedagogy in the "classroom without borders," including the integration of transitional justice field work opportunities for students in their academic programs, offers educators the occasion to begin making productive connections in learning, research, and service between these fields (Figure 5).

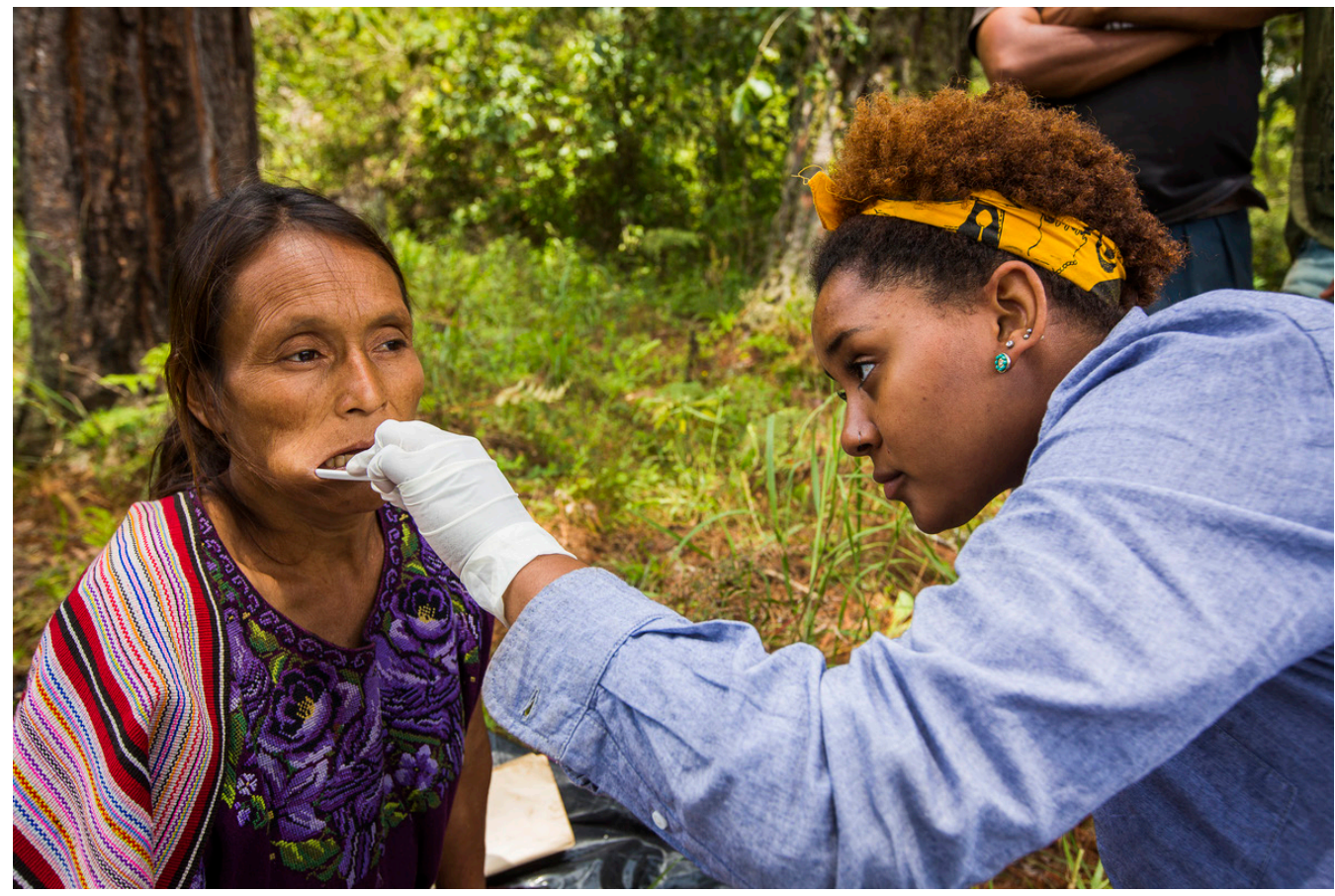

Figure 4. A student collects a cheek swab for a DNA sample from an Ixil woman, whose brother was murdered. (Photograph:Tristan Brand). ${ }^{57}$

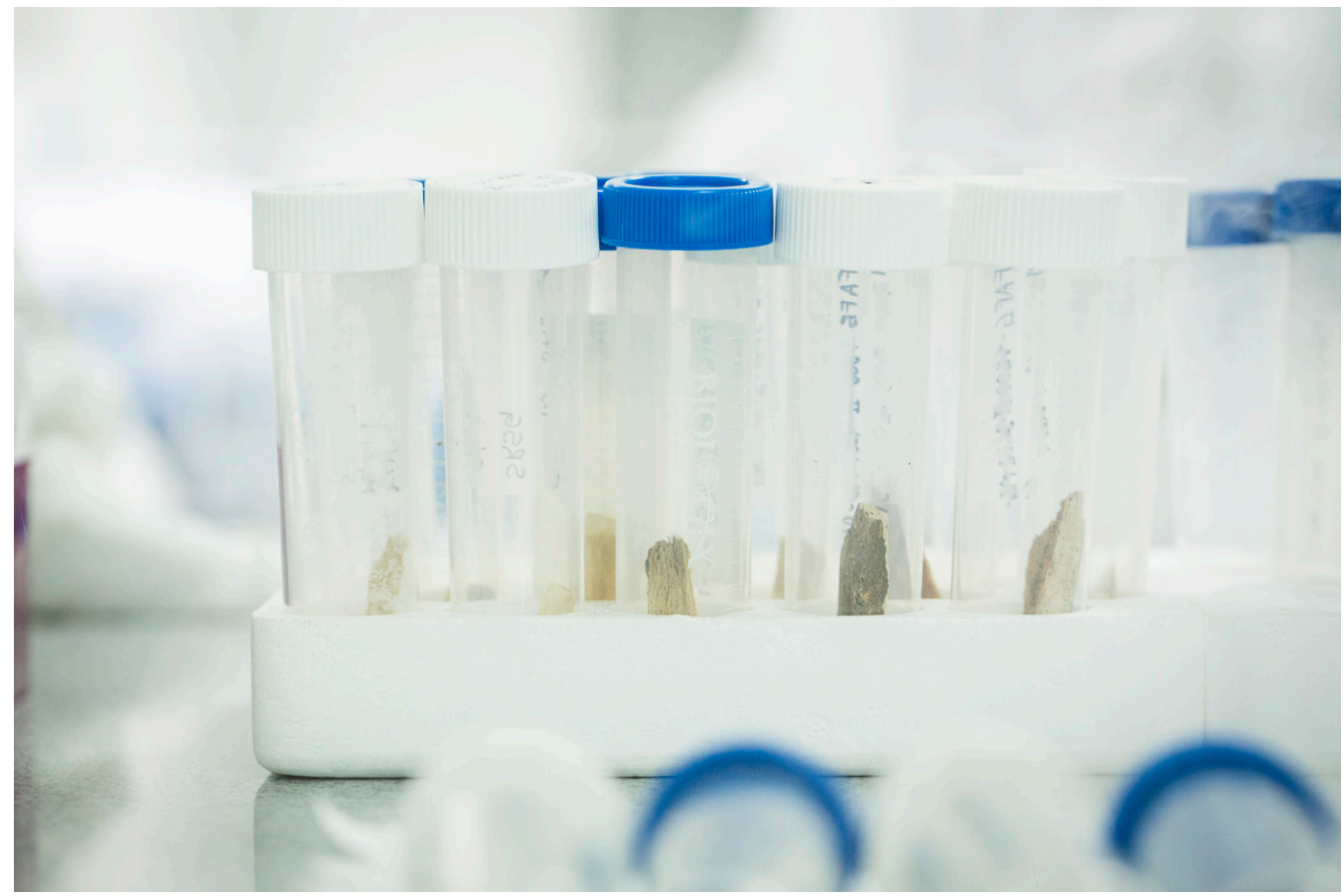

Figure 5. Fragments of bone at a DNA laboratory in Guatemala City.

DNA samples from over 6000 sets of human remains, taken from over 1000 burial sites have been analyzed at the Guatemalan Forensic Anthropology Foundation's (FAFG's) Headquarters. (Photograph:Tristan Brand). ${ }^{61}$ 
Data collection platforms, like KoBo, are "driven by actual field-based needs and challenges such as limited technical know-how" ${ }^{2}$ The practical evolution of these platforms makes their use feasible even in remote areas. In these settings, where remote sensing and data collection represent "a substantial paradigm shift from traditional, often retrospective, collection of evidence corroborating alleged human rights violations", ${ }^{63}$ as in the experience of the Satellite Sentinel Project (SSP), the need is still urgent to report "predisposing factors" to mass violence and to document observations from the ground, especially in the majority of cases when monitoring from the sky is not possible (Figure 6).

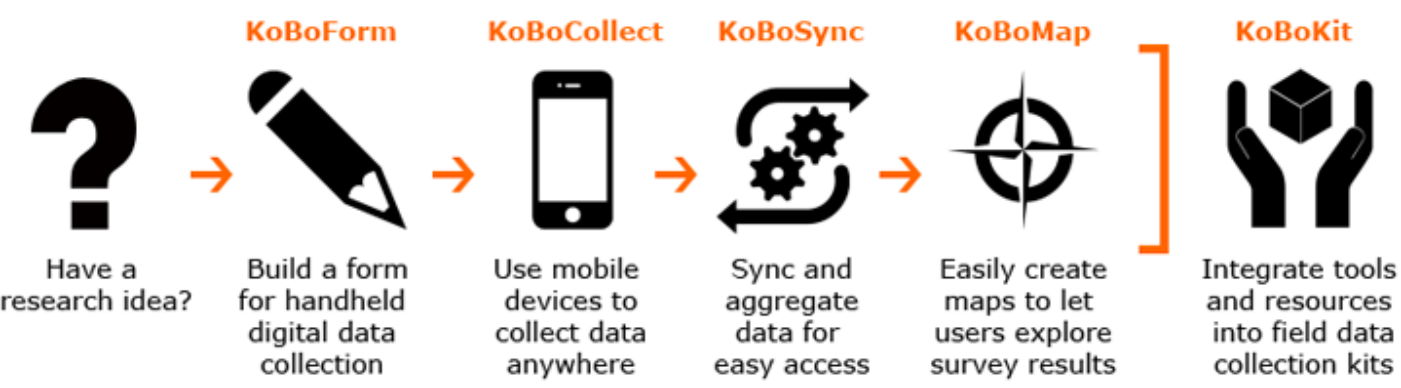

Figure 6. Kobo platform (Source: http://irevolution.net/2012/05/08/kobo-platform/).

The search for documented evidence must utilize scientific inquiry as "the right to truth" in post-conflict societies becomes more critical to understand "the circumstances of past human rights violations in order to prevent their recurrence". ${ }^{64}$ Physicians for Human Rights engages in "forensic human identification projects" in a growing number of countries, including Cyprus, Guatemala, Colombia, and, most recently, in Afghanistan ${ }^{65}$ and Libya. The Director of PHR's International Forensics Program, Stefan Schmitt, provided an opportunity to Cristian Silva, Director, International Field Initiatives in Forensic Training (IFIFT), to attend one of the PHR programs, which led to the idea of the Multidisciplinary Field School in Guatemala pioneered by Fredy Peccerelli.

The need to establish the "necessary forensic infrastructure in transitional justice contexts" ${ }^{66}$ presents tremendous challenges for local areas. For this reason, education makes a critical difference in the various countries where Physicians for Human Rights mobilizes colleagues to implement projects. The Multidisciplinary Field School experience of transitional justice in Guatemala provides one example. It is insufficient to introduce humanitarian technologies exported from outside the area where genocide occurs. In the absence of a local infrastructure, without the recognition of the legal, technical, and scientific perspectives to define and determine the scope of mass fatality, how can there be justice to address the rights of victims or the obligations of a state in question when we speak in the literature of "never again?" (Figure 7.) ${ }^{67}$

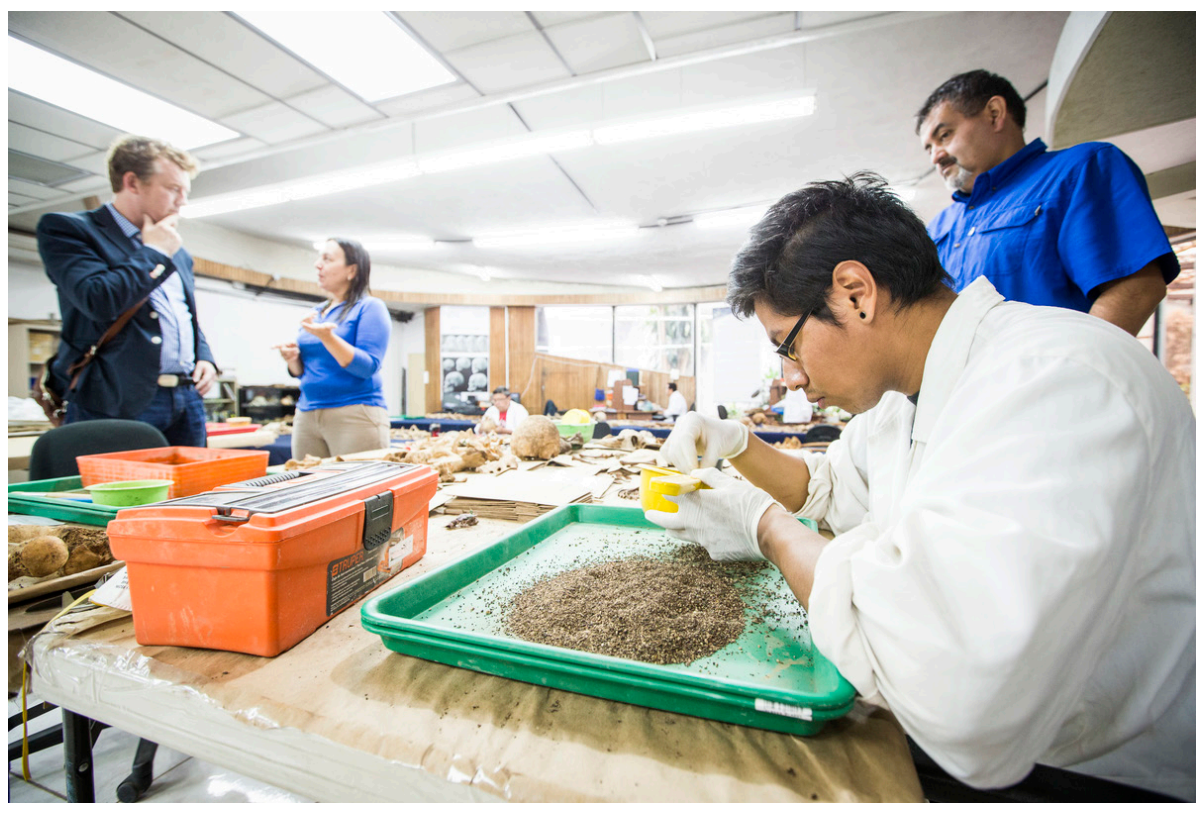

Figure 7. A forensic anthropologist works to isolate fragments of human bone from other materials. Human remains are registered, analyzed, and a biological profile is built to help identify victims and their cause of death. (Photograph: Tristan Brand). ${ }^{68}$ 
The experiences of Physicians for Human Rights in Afghanistan prompt additional reflections that reference the "regime type and the state" in national-level approaches to explain why genocide occurs, ${ }^{69}$ as we acknowledge the limits of humanitarian technologies in our search for "clues to future prevention".70 In Afghanistan, perpetrators of past crimes are often in power with some leaders "implicated in on-going abuses". In thinking about "international justice in preventing human rights abuses" as one of the "pillars of prevention",72 we must acknowledge formidable blockages at the national level. The Sharia principle that only victims can forgive is difficult to reconcile with their pursuit of justice in an environment that does not provide for safe access to the judiciary to urge the investigations of past crimes. ${ }^{73}$ Given the serious challenges to the rule of law in Afghanistan, ${ }^{74}$ training courses and projects for civil society groups there provided skills in basic crime scene documentation and allowed students to participate in the exhumation of a set of human remains in a single grave located in the Ministry of the Interior compound (Figure 8). ${ }^{75}$

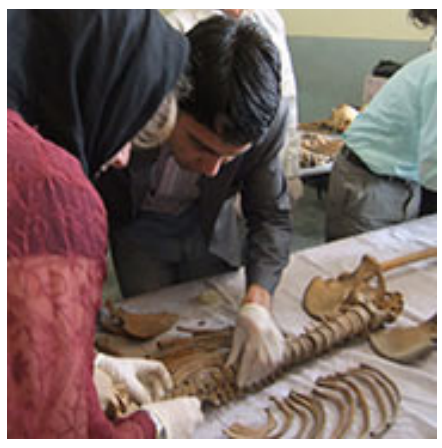

Figure 8. Exhumation of a set of human remains at the Ministry of Interior Compound (Source:

http://physiciansforhumanrights.org/library/reports/securing-afghanistans-past-gap-analysis-report.html).

Afghanistan's civil society faces tremendous obstacles to influence policy on issues of transitional justice. The lack of coordination among civil society organizations (CSOs) as well as between local and international organizations is cited as most problematic in their efforts "to keep the idea of transitional justice alive" 76 in the country. One consequence of the dedication to local training by Physicians for Human Rights was the founding in 2011 of the Afghanistan Forensic Science Organisation (AFSO) with "the stated objective to document and secure the country's mass grave sites." 77 The following year humanitarian technologies, including Global Positioning System (GPS) surveying, ${ }^{78}$ were used to document thirteen mass graves with forensic reports issued to local and judicial authorities, civil society as well as victim organizations. ${ }^{79}$

The uses of humanitarian technologies can make a difference if their applications may be referenced to strengthen the connection between "expert" and local knowledge in a sustained effort to avoid marginalizing local experiences and practices, ${ }^{80}$ as in AFSO initiatives to conduct awareness raising workshops in the communities where mass graves were surveyed and documented. ${ }^{81}$ As research is undertaken that pertains to local initiatives, particular data ethics questions come to light, to which this inquiry must now turn.

\section{Civil Society and Data Ethics: Queries for a New Era The Impact of Humanitarian Technologies on Genocide Prevention Research}

In the early twenty-first century, the ways in which digital technology applications and data collection methods impact on education raise unprecedented questions. As the genocide studies community reflects on the influence of humanitarian technologies in prevention efforts, academics and activists alike must grapple with data ethics in a holistic manner. While research still "remains largely unconnected and 'silo-ed" 82 in the fields of transitional justice and genocide studies, "data increasingly flows through and is used by people and organizations across sectors and across domains." ${ }^{83}$ This is one of the points made during "The Social, Cultural, and Ethical Dimensions of 'Big Data” conference organized in New York City on March 17, 2014 by the Data \& Society Research Institute, the White House Office of Science \& Technology Policy, and New York University's Information Law Institute.

Civil society must grapple increasingly with the ethics of what is known as "big data," defined in one way as "things one can do at a large scale that cannot be done at a smaller one to extract new insights or create new forms of value in ways that change markets, organizations, the relationship between citizens and governments." ${ }^{84}$ In this context, "the relationship between big data uses and power, notably the issue of 
power differentials in relation to data analytics," ${ }^{\prime 5}$ is particularly relevant to reflections in the genocide studies community. More fundamentally, if "society will need to shed some of its obsession for causality in exchange for simple correlations: not knowing why but only what," 86 attention must be focused more normatively, and much more purposefully, on the ways in which "those who are tracked by data analytics may lose access to their information or may be unaware of how it is being used." 87

The normative focus of inquiry is of particular relevance to cases long neglected in genocide prevention research, which pertain to sexual violence in conflict. Do constructivist and feminist perspectives sufficiently inform research analyzing women's victimization in comparative studies? ${ }^{88}$ In asking this question, researchers must rely increasingly on sensitive data, which documents sexual violence in cases ranging from the Democratic Republic of Congo to the Republic of Colombia. In these cases, there are specific needs that involve establishing procedures, identifying best practices, and upholding professional ethics, ${ }^{89}$ which are each critical in reflecting on the ways data ethics impacts on research in the genocide studies community.

As we consider the need to establish procedures to protect the vulnerable, interviewers must be specifically trained to document evidence of sexual violence in conflict, which may be used to prosecute the perpetrators. There are specific responsibilities interviewers have in this context, including to evaluate safety and security risks to the interviewees, to learn how to craft ethical and open-ended questions, and to focus on obtaining informed consent from the interviewees. ${ }^{90}$

The identification of best practices highlights civil society's responsibility to address the "social structure of denial"91 and to map local, communal, regional, national, and global actors engaged to end sexual violence in conflict. What are the best practices that allow civil society actors to share widely testimonies of survivors of sexual violence in conflict using social media and mobile technology without endangering victims? In addition, best mapping practices must be identified, which may offer a graphic overview of tensions in civil society, including local communities in conflict, without exposing those on the ground to physical danger.

The commitment to uphold professional ethics requires those who conduct field research to collect evidence of sexual violence in conflict using humanitarian technologies to fulfill their responsibility to communicate with the Institutional Review Boards for Protection of Human Subjects at their respective universities. As more field work integrates sensitive data that is accessible, this commitment still does not consistently address the fact that "even when researchers try to be cautious about their procedures, they are not always aware of the harm they might be causing in their research." 92 Their responsibility is to uphold professional ethics involving potential harm, consent, and disclosure of the data acquired. This is particularly significant in thinking about how to upload local narratives ${ }^{93}$ to avoid marginalizing local experiences, as we address a global policy concern by disclosing testimonies of sexual violence in conflict.

Sexual violence in conflict is a crime against humanity, which "as international case law develops... when intended to destroy a group, will most likely be declared genocide on the basis of the five acts listed in Article II of the Convention". 94 These acts are: "(a) Killing members of the group; (b) Causing serious bodily or mental harm to members of the group; (c) Deliberately inflicting on the group conditions of life calculated to bring about its physical destruction in whole or in part; (d) Imposing measures intended to prevent births within the group; and (e) Forcibly transferring children of the group to another group"..$^{9}$

The broad campaign to stop rape now involves global civil society defined by Castells as local community engagement, the evolution of non-governmental organizations, the development of social movements, and public opinion mobilization. ${ }^{96}$ The "glocal" ${ }^{97}$ process aims to upload accurately and securely data, the firsthand testimonies of local experiences to inform a global conversation on sexual violence in conflict, which connects survivors directly to activists. ${ }^{98}$ This process aims to exert constant pressure on states whose leaders are complicit in the mass rape of women.

Civil society is increasingly responsible to collect, organize, and share the most sensitive data, acquired through humanitarian digital technologies, to combat sexual violence in conflict. Transnational advocacy networks, particularly non-governmental organization (NGO) activists, are called to use this data obtained within complicit states in the search for justice and to effect transformative change. There is a broad array of ethical questions in research design, particularly related to data collection and storage during the field experience before embarking on analysis and reporting, as these relate to genocide prevention in this particular case. The genocide studies community has the responsibility to begin its outreach to colleagues, such as those in the Ethics of Data in Civil Society (EoD) network, who are working to formulate "principles of ethical digital data use in civil society that might stand the test of time and weather the pace of innovation, both in technology and in civil society organizing". 99 


\section{Conclusion}

The applications of humanitarian technologies in genocide studies may increasingly focus our attention on the restorative justice approach and pillars of prevention, notably the need for "a continuous flow of accurate information on emerging conflicts" ${ }^{100}$ Our ethical responsibility in research is to question consistently if the integration of data acquired through humanitarian technologies empowers or marginalizes survivors. As younger and younger victims increasingly suffer human rights atrocities around the world, "public awareness of the plight of children and of what is or is not being done to alleviate it, has been greatly heightened by the instant media access which is a feature of life in twenty-first century society". ${ }^{101}$

May the voices of the marginalized in conflict areas also be heard in accordance with the principles of the Universal Declaration of Human Rights? ${ }^{102}$ A future challenge for genocide prevention is to identify through comparative analyses the ethical uses of humanitarian technologies by researchers, particularly to acquire data from post-conflict areas during investigations of "predisposing and precipitating factors". ${ }^{103}$

As "big data" becomes available and the digital revolution drives "much of the increasing complexity and pace of life we are now seeing,"104 the temptation exists in research to reduce individuals and societies to "communication systems, without much concern for the substance of the "messages" these networks carry". 105 The ethical foundation of genocide prevention research is in the substance of the messages. Progressively, are researchers likely to be "strategically positioned within national contexts"106 as "rooted cosmopolitans"107 to interpret the messages conveyed? Their presence as such is necessary to actualize the promise offered by humanitarian technologies in genocide studies.

\section{Endnotes}

1 Joyce Apsel, "Research and Teaching about Genocide," in Genocide Matters, eds. Joyce Apsel and Ernesto Verdeja (New York: Routledge, 2013): 127-49.

2 Alexander L. Hinton, "Critical Genocide Studies," in Genocide Matters, eds. Joyce Apsel and Ernesto Verdeja (New York: Routledge, 2013): 42-58.

3 Jessica T. Mathews, "Power Shift." Foreign Affairs (1997): 50-66.

4 Manuel Castells, "The New Public Sphere: Global Civil Society, Communication Networks and Global Governance." ANNALS (2008): 78-93.

5 Taylor Owen, "Disruption Foreign Policy in a Networked World," Pierre Elliott Trudeau Foundation, Summer Institute (2012): 4.

6 Shae Garwood, Advocacy Beyond Borders: NGOs, Anti-Sweatshop Activism, and the Global Garment Industry (Bloomfield, CT: Kumarian, 2011): 2.

7 Miles Kahler, Networked Politics: Agency, Power and Governance (New York: Cornell, 2009).

8 Garwood, Advocacy Beyond Borders, 2.

9 Taylor Owen, "Disruption Foreign Policy in a Networked World," Pierre Elliott Trudeau Foundation, Summer Institute (2012): 4.

10 Ernesto Verdeja, “Transitional Justice and Genocide," in Genocide Matters, eds. Joyce Apsel and Ernesto Verdeja (New York: Routledge, 2013): 172-94.

11 http://howtobuildpeace.org/build-peace-2014/.

12 David A. Hamburg, Preventing Genocide (Boulder: Paradigm Publishers, 2010): 2-18.

13 Maureen S. Hiebert, "Questioning Boundaries," in Genocide Matters, eds. Joyce Apsel and Ernesto Verdeja (New York: Routledge, 2013): 16-41.

14 Iavor Rangelov, “The Role of Transnational Civil Society," in Responding to Genocide. (Boulder: Lynne Rienner, 2013): 135-55.

15 Castells, "The New Public Sphere," 78-93.

16 Hamburg, Preventing Genocide, 2-18.

17 Iavor Rangelov, “The Role of Transnational Civil Society, in Responding to Genocide (Boulder: Lynne Rienner, 2013): 135-55.

18 Susan Benesch "Countering Dangerous Speech to Prevent Mass Violence during Kenya's 2013 Elections." Final Report (Washington, DC: United States Institute of Peace, 2014): 1-26.

19 Hamburg, Preventing Genocide, 2-18.

20 Morton Deutsch, "Justice and Conflict," in The Handbook of Conflict Resolution, eds. Morton Deutsch and Peter T. Coleman (San Francisco: Jossey-Bass, 2014): 29-55.

21 Hiebert, "Questioning Boundaries," 16-41.

22 Hamburg, Preventing Genocide, 2-18.

23 Joshua Goldstein and Juliana Rotich, "Digitally Networked Technology" in Kenya's 2007-2008 Post-Election Crisis (The Berkman Center for Internet \& Society at Harvard University, September 2008): 1-10. 
24 Eviatar Zerubavel, The Elephant in the Room Silence and Denial in Everyday Life (Oxford: Oxford University Press, 2007): 61-72.

25 Margaret Keck and Kathryn Sikkink, Activists Beyond Borders (New York: Cornell, 1998): 1-38.

26 Hamburg, Preventing Genocide, 2-18.

27 Susan Wolfinbarger and Jessica Wyndham, “Remote Visual Evidence of Displacement," Forced Migration 38 (2011): $20-21$.

28 Hamburg, Preventing Genocide, 19-35.

29 Hiebert, “Questioning Boundaries," 16-41.

30 Christopher Kojm, Global Trends 2030: Alternative Worlds (Washington, DC: National Intelligence Council, 2012).

31 Hiebert, “Questioning Boundaries," 16-41.

32 Scott Edwards, "Field Work from the Sky: Remote Data Collection from Active Conflict Zones (The Case of Darfur)." Unpublished Paper. International Sudan Studies Association. Annual Conference (2009): 1-9.

33 http://www.amnestyusa.org/research/science-for-human-rights/eyes-on-darfur.

34 Edwards, "Field Work from the Sky," 1-9.

35 http://www.amnestyusa.org/research/science-for-human-rights/eyes-on-darfur.

36 http://irevolution.net/2010/12/30/sat-sentinel-project/.

37 Taylor Owen and Ben Kiernan, “Bombs Over Cambodia”, The Walrus (2006): 62-69.

38 Scott Edwards (in response to Meier) 2010, http://irevolution.net/2010/12/30/sat-sentinel-project/.

39 Nathaniel A. Raymond, Benjamin I. Davies, Brittany L. Card, Ziad Al Achkar, and Isaac L. Baker, "While We Watched: Assessing the Impact of the Satellite Sentinel Project," in Science \& Technology 14 (2013): 185-91.

40 Frank Chalk, Kyle Matthews, and Carla Barqueiro, Mobilizing the Will to Intervene: Leadership to Prevent Mass Atrocities (Montreal: McGill-Queen's University Press, 2010): 3-21, http://migs.concordia.ca/W2I/home.htm.

41 Edwards, "Field Work from the Sky," 7.

42 Verdeja, “Transitional Justice and Genocide”, 179.

43 Edwards, "Field Work from the Sky," 7.

44 Verdeja, “Transitional Justice and Genocide," 174.

45 Wolfinbarger and Wyndham, "Remote Visual Evidence of Displacement," 20-21.

46 Nathaniel A. Raymond et al., "A New Forensics: Developing Standard Remote Sensing Methodologies to Detect and Document Mass Atrocities," (Unpublished Paper. Cambridge, 2014): 1-24.

47 Colette Mazzucelli and A. Nicholas Fargnoli, "Ethics and International Relations in Today's Classrooms without Borders," Carnegie Council, https://www.carnegiecouncil.org/education/001/ethics/0004.html/. Accessed September 21, 2014.

48 http://ifift.org/.

49 www.fafg.org.

50 Kyle Matthews, “Digging for Truth in Guatemala," OpenCanada.org, http://opencanada.org/ features/the-think-tank/essays/ digging-for-truth-in-guatemala/. Accessed September 21, 2014.

51 Walter Paniagua, Guatemala resists forgetting: Post-Conflict Memory Initiatives, (Utrecht, The Netherlands: Impunity Watch, 2012 ): 8.

52 Verdeja, “Transitional Justice and Genocide," 180.

53 Paniagua, Guatemala Resists Forgetting: Post-Conflict Memory Initiatives, 9.

54 http://opencanada.org/features/the-think-tank/essays/digging-for-truth-in-guatemala/.

55 Verdeja, “Transitional Justice and Genocide”, 181.

56 Paniagua, Guatemala Resists Forgetting.

57 http://opencanada.org/features/the-think-tank/essays/digging-for-truth-in-guatemala/.

58 Stefan Schmitt, Amanda Sozer, Gillian Fowler, and Dallas Mazoori, "Physicians for Human Rights - The Role of Forensic Archeology in Transitional Justice Contexts.” (Unpublished Paper. Florida, 2014): 1-21.

59 Verdeja, “Transitional Justice and Genocide”, 182.

60 Verdeja, “Transitional Justice and Genocide," 174.

61 http://opencanada.org/features/the-think-tank/essays/digging-for-truth-in-guatemala/.

62 http://irevolution.net/2012/05/08/ kobo-platform/.

63 Raymond et al., "While We Watched: Assessing the Impact of the Satellite Sentinel Project," 187.

64 Schmitt, Sozer, Fowler, and Mazoori, "Physicians for Human Rights," 1-21.

65 http://physiciansforhumanrights.org/library/reports/securing-afghanistans-past-gap-analysis-report.html, 81-84.

66 Schmitt, Sozer, Fowler, and Mazoori, "Physicians for Human Rights," 1-21. 
67 Ibid; Peter Ronayne. Never Again?: The United States and the Prevention and Punishment of Genocide since the Holocaust (Lanham, MD: Rowman \& Littlefield, 2001).

$68 \mathrm{http}: / /$ opencanada.org/features/the-think-tank/essays/digging-for-truth-in-guatemala/.

69 Hiebert, "Questioning Boundaries," 25-30.

70 Hamburg, Preventing Genocide, 10.

71 Schmitt, Sozer, Fowler, and Mazoori, "Physicians for Human Rights," 10.

72 Hamburg, Preventing Genocide, 17.

73 Schmitt, Sozer, Fowler, and Mazoori, "Physicians for Human Rights," 10.

74 http://physiciansforhumanrights.org/library/reports/securing-afghanistans-past-gap-analysis-report.html.

75 Schmitt, Sozer, Fowler, and Mazoori, "Physicians for Human Rights," 10.

76 Afghanistan Justice Organization, “Transitional Justice in Afghanistan: We should not repeat old issues?” Policy Note. Kabul: AJO, (2013), 7.

77 Schmitt, Sozer, Fowler, and Mazoori, "Physicians for Human Rights," 13.

78 GPS.gov, "Survey \& Mapping., http://www.gps.gov/applications/survey/. Accessed September 21, 2014.

79 Schmitt, Sozer, Fowler, and Mazoori, "Physicians for Human Rights," 13.

80 Verdeja, “Transitional Justice and Genocide," 189.

81 Schmitt, Sozer, Fowler, and Mazoori, "Physicians for Human Rights," 13.

82 Verdeja, "Transitional Justice and Genocide," 174.

83 Data \& Society, "Event Summary: The Social, Cultural, \& Ethical Dimensions of 'Big Data." New York, 2014, http://www. datasociety.net/pubs/2014-0317/BigDataConferenceSummary.pdf, (accessed September 21, 2014): 1.

84 Viktor Mayer-Schönberger and Kenneth Cukier, Big Data (Boston: Mariner Books, 2014): 6.

85 Data \& Society, "Event Summary: The Social, Cultural, \& Ethical Dimensions of 'Big Data," 3.

86 Mayer-Schönberger and Cukier, Big Data, 7.

87 Data \& Society, "Event Summary: The Social, Cultural, \& Ethical Dimensions of 'Big Data"' 4.

88 Roger W. Smith, "Genocide and the Politics of Rape," in Genocide Matters, eds. Joyce Apsel and Ernesto Verdeja (New York: Routledge, 2013): 82-105.

89 Nathaniel A. Raymond, Brittany Card, Isaac Baker, Colette Mazzucelli, Maria-Helen Maras, and Michelle D. Miranda, "Current Challenges: Information Communication Technologies for Human Rights Documentation" White Paper (Build Peace. Cambridge: MIT Media Lab, 2014): 4-5.

90 Video for Change, "Conducting Safe, Ethical, and Effective Interviews with Survivors of Sexual and Gender-Based Violence," (New York: Witness, 2014).

91 Zerubavel, The Elephant in the Room Silence and Denial in Everyday Life, 47-60.

92 Danah Boyd and Kate Crawford, "Six Provocations for Big Data." Unpublished Paper. Oxford Internet Institute's “A Decade in Internet Time: Symposium on the Dynamics of Internet and Society," (2011): 10.

93 Manuel Castells, Networks of Outrage and Hope (New York: Polity, 2012): 1-19.

94 Smith, "Genocide and the Politics of Rape," 100.

95 United Nations Convention on the Prevention and Punishment of Genocide 1948, http://www.preventgenocide .org/law/ convention/text.htm.

96 Castells, “The New Public Sphere," 83-7.

97 Julia Tagüeña, “'Glocal' approach makes global knowledge local.” SciDev.net, http://www.scidev.net/global/communication/ opinion/-glocal-approach-makes-global-knowledge -local.html. Accessed September 21, 2014.

98 Mary Kaldor, Global Civil Society: An Answer to War (New York: Polity, 2003): 1-14.

99 The Ethics of Data in Civil Society 2014, http://www.scribd.com/doc/237526683/EthicsofData-FRAMINGDOCUMENT.

109 Hamburg, Preventing Genocide, 17.

101 Philip Alston and John Tobin, Laying the Foundations for Children's Rights (Florence: The UNICEF Innocenti Research Centre, 2005): 51.

102 Universal Declaration of Human Rights 1948 (http://www.un.org/en/ documents/udhr/).

103 Hamburg, Preventing Genocide, 19.

104 Geoffrey West, "Big Data Needs a Big Theory to Go with It." ScientificAmerican.com, http://www.scientificamerican.com/ article/big-data-needs-big-theory/. Accessed September 21, 2014.

105 Stanley Hoffmann, Contemporary Theory in International Relations (Englewood Cliffs, N.J.: Prentice-Hall, Inc, 1960): 46. 
106 Garwood, Advocacy Beyond Borders, 9.

107 Sidney Tarrow, The New Transnational Activism (Cambridge: Cambridge University Press, 2005). 